\title{
Chapter 21 \\ Climate Change and Children: An Issue of Intergenerational Justice
}

\author{
Ann V. Sanson and Susie E. L. Burke
}

\subsection{Introduction}

The 2015 Paris Agreement reflected global acknowledgement that climate change is "an urgent and potentially irreversible threat to human societies and the planet". Scientists view it as the biggest global health threat of the twenty-first century (Costello et al., 2009). In terms of Bronfenbrenner and Morris's (2006) ecological model, ${ }^{1}$ climate change is quintessentially a macro-system phenomenon, but its impacts are felt at every level of the system, from macro to micro. It poses substantial and escalating risks for food security, water availability, health, housing, infrastructure, agriculture and natural ecosystems (IPCC, 2014). There is a deep inequality in its causes and its impacts: disproportionately caused by the developed world, it will disproportionately affect the developing world; and children and future generations will disproportionately suffer its consequences. And yet peace psychology has been slow to consider climate change as a "peace issue". This chapter positions climate change as an urgent issue of structural violence and intergenerational justice that demands attention from psychologists, scholars, practitioners, activists and policy-makers, with particular emphasis on the needs of current and future generations of children.

\footnotetext{
${ }^{1}$ Bronfenbrenner and Morris's (2006) ecological model categorises influences on child development from the micro-system (the child's immediate family context) through the meso- and exosystems (interacting social influences such as school and health care) to the macro-system (national, cultural and global factors).
}

\author{
A. V. Sanson (凶) \\ University of Melbourne, Parkville, VIC, Australia \\ e-mail: annvs@unimelb.edu.au \\ S. E. L. Burke \\ Australian Psychological Society, Melbourne, VIC, Australia
}

(C) The Author(s) 2020

N. Balvin, D. J. Christie (eds.), Children and Peace, Peace Psychology Book

Series, https://doi.org/10.1007/978-3-030-22176-8_21 
After a brief outline of climate science, we examine how climate change contributes to both direct and structural violence. We then turn to the many ways in which children and youth are affected by climate change. Next we examine what a fair and just response to climate change might look like and discuss the many ways all of us can contribute towards making this a reality. We conclude by noting that, while climate change poses a dire threat, our responses to it can contribute significantly to a healthier, more equitable and more peaceful world.

\subsection{The Science of Climate Change}

Climate change refers to the warming of the planet caused by the build-up of greenhouse gases in the atmosphere (principally carbon dioxide, methane and nitrous oxide). As concentrations of $\mathrm{CO}_{2}$ in the atmosphere have increased (Betts, Jones, Knight, Keeling, \& Kennedy, 2016), global temperatures have risen in parallel. All of the world's ten warmest years have occurred since 1998, and the Earth has not been so warm for 115,000 years (NOAA, 2017). Climate change is responsible for increased frequency and severity of extreme weather events (EWEs) such as floods, hurricanes and bushfires, as well as slower impacts like rising sea levels, droughts and changed growing seasons.

The climate science indicates that we must act with urgency to move beyond fossil fuels and eliminate man-made emissions of greenhouse gases while at the same time drawing down the excess greenhouse gases in the atmosphere. Without such rapid change, further warming of up to $4.8^{\circ} \mathrm{C}$ can be expected during the twentyfirst century (IPCC, 2014). This would be catastrophic, potentially threatening the entire global ecosystem and human civilisation.

The Paris Agreement committed nations to limit the temperature increase to below $2{ }^{\circ} \mathrm{C}$, preferably below $1.5^{\circ} \mathrm{C}$. Cooperation by all countries is needed to achieve the required deep reductions in emissions. But, although most of the technological solutions to both halting emissions and drawing down excess carbon are already available (e.g. Hawken, 2017), action is not happening nearly fast enough (The Royal Society, 2017).

\subsection{Climate Change, Children and Youth}

There are several reasons to focus particularly on the impact of climate change on children and young people, three of which are discussed below. 


\subsubsection{Children's Greater Vulnerability to Climate Change Impacts}

Since climate change disrupts the basic necessities of life - shelter, food and water it is regarded as the biggest global human health threat of the twenty-first century (Costello et al., 2009). There is clear evidence that it will exacerbate the underlying social, economic and ecological factors that cause global illness and premature death for all age groups (Watts et al., 2018). However, those most vulnerable to climate change impacts are children and youth, with the World Health Organization estimating that children will suffer more than $80 \%$ of the illnesses, injuries and deaths attributable to it (McMichael et al., 2004). Due to their immature physiological defence systems and the ways they interact with their immediate environment, they are physically more vulnerable to the direct effects of extreme heat, drought and natural disasters (McMichael, 2014) through injuries, environmental toxins and infectious, gastrointestinal and parasitic diseases that will become more prevalent with warmer temperatures and changed rainfall patterns (Sheffield \& Landrigan, 2010). For example, comparing the year 2000 with the three decades preceding it, climate change is estimated to have increased the numbers of cases of undernutrition, diarrhoeal diseases and vector-borne diseases such as malaria by $3-10 \%$ (Confalonieri et al., 2007), a trend that is expected to accelerate (Ebi, 2014).

Children are also more susceptible to indirect effects of climate change, such as food shortages, intergroup conflict, economic dislocation and migration (Akresh, 2016). Particularly for younger children, their dependency on adults can lead to psychosocial consequences through the impact of climate-related extreme weather events (EWEs) on parents' physical, emotional and social well-being, family functioning and economic status (Clayton, Manning, Krygsman, \& Speiser, 2017). Children also face danger in the period following EWEs when their routines and safety nets are disrupted, and they are vulnerable to physical and sexual violence, recruitment into armed groups, early marriage, trafficking and child labour (The Child Protection Working Group, 2015). There is also growing evidence of psychosocial impacts. Climate-related EWEs have been linked to consequences including post-traumatic stress disorder, depression, panic, sleep and anxiety disorders, cognitive deficits, learning problems and impaired language development (Garcia \& Sheehan, 2016).

Psychosocial impacts of climate change arise not only from directly experiencing its effects but also from vicarious experience and knowledge of the threat it poses for the future. There is clear evidence of widespread emotional reactions to climate change, even in high-income countries that are not yet suffering its direct effects. Surveys have found that many young people experience fear, sadness, anger and a sense of powerlessness (Ojala, 2015; Strife, 2012; UNICEF UK, 2013). Around the world, large numbers of youth recognise that climate change poses a serious threat (e.g. 60\% of Australian 16- to 17-year-olds; Tranter \& Skrbis, 2014) and are worried about how it will affect their own futures (e.g. 74\% of British 11- to 16-year-olds; UNICEF UK, 2013) as well as those of children and families in developing countries (63\% in the British sample above). Many young people believe 
that the world may end during their lifetime due to climate change and other global threats (Albert, Hurrelmann, Quenzel, \& Jugend, 2010). Thus there is concern about how the threat of climate change is affecting the next generation's capacity to invest in the future (Sanson, 2017).

Further, impacts on children's and youth's physical, psychological, social and cognitive development will carry sequelae right through their lifetimes and possibly beyond. They can have long-term developmental, educational and economic consequences which make it harder for them to reach their full potential (Clayton et al., 2017; Grantham-McGregor et al., 2007). This, along with likely epigenetic changes, may diminish their capacity to care for the next generation, creating a vicious intergenerational cycle of disadvantage that impedes human development.

\subsubsection{Double Jeopardy for Children in Disadvantaged Circumstances}

A further injustice arises from the fact that not all children and youth will suffer equally from climate change. Both physical and psychosocial impacts can be understood as the consequence of the accumulation of risk factors and the attenuation of protective factors in children's lives, along with repeated exposure to stressful situations (Sanson, Wachs, Koller, \& Salmela-Aro, 2018). As discussed in Sect. 21.4, the most serious impacts of climate change are predicted in low- to-middle-income countries (LMICs), where $85 \%$ of the world's children live (UNICEF, 2014). These children, along with children in disadvantaged circumstances in developed countries, will thus experience more risk factors and fewer protective factors. Since children are already at greater risk of climate change effects than adults, children growing up in situations experiencing the worst climate change effects are in double jeopardy.

Unless We Act Now (UNICEF, 2015) clearly explains how climate change disproportionately affects the poorest children, deepening existing inequalities. Figure 21.1 graphically illustrates this with the example of drought. Those with adequate resources can safely relocate, keep families together, access health care, maintain children's education and reduce social stressors, whereas those without such resources find themselves on an escalating downwards path of long-term deprivations like poorer nutrition, limited access to safe drinking water and disruptions to schooling. For these children, intergenerational injustice is compounded with exacerbated inequalities.

\subsubsection{Demands for Coping and Adaptation Placed on the Next Generation}

Children and youth will need to adapt to major changes arising from climate change, which are already starting but will escalate even with speedy action to curb emissions. The direct, indirect and gradual impacts of climate change all bring obvious 


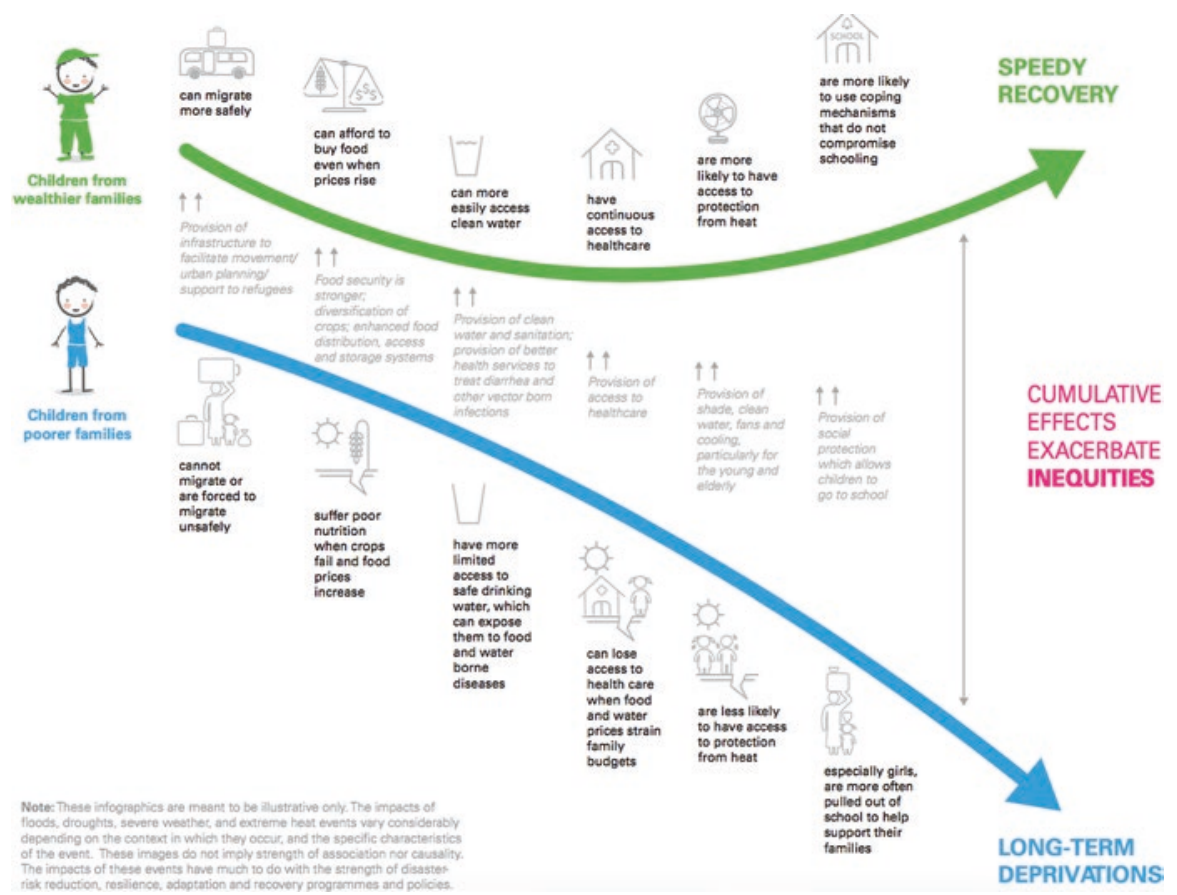

Fig. 21.1 Illustration of how climate change can exacerbate inequities, using the example of climate change-induced drought (Source: UNICEF (2015) Unless we act now (Fig. 7, p27))

developmental challenges for young people. Dislocation, loss of place, migration and social disruptions will be added challenges for many (see Sect. 21.4).

Additionally, restoring a safe climate requires a rapid transition to a low-carbon economy, involving major restructuring of industry, transport, energy and food production. Therefore this generation of children and youth will need to change how they live, eat, work, travel and consume.

We need to think about the knowledge, skills and attitudes that will help the next generation adapt and cope successfully with the massive changes ahead. Section 21.6 provides discussion of the role of adults in equipping children for these challenges.

\subsection{Climate Change, Peace and Violence}

The $2 \times 2$ matrix developed by Christie, Wagner, and Winter (2001), that differentiates between episodic (direct) violence and structural violence and episodic and structural peace-building, provides a useful framework for considering how climate change relates to peace and violence. Below we discuss how it contributes to both 
episodic and structural violence, while Sect. 21.5 outlines the potential for restoring a safe climate while simultaneously building more peaceful, healthy and equitable communities.

\subsubsection{Climate Change's Contribution to Direct Violence}

Lab-based and quasi-experiments have demonstrated a causal relationship between heat and aggression (Anderson, 2012). In a meta-analysis covering several centuries and continents, Burke, Hsiang, and Miguel (2015) found that both hotter temperatures and lower rainfall were related to increases in all forms of violence, from interpersonal to international, but particularly intergroup violence. Akresh (2016) cites evidence of links between increasing temperature and crime, community violence and civil war. As the temperature goes up, so does aggression.

Other factors often mediate the link between climate change and direct violence. Climate change effects (e.g. shortages of food and water, changed growing seasons and forced migration) can reduce social control and create social conflict, hence leading to violence (Agnew, 2011). When communities are disrupted due to EWEs or slower-acting climate change effects like droughts and rising sea levels, increasing levels of frustration in society can lead to interpersonal violence. For example, domestic abuse increased among families who experienced Hurricane Katrina in the USA (Yun, Lurie, \& Hyde, 2010), and violence towards women increased in communities affected by the Australian "Black Saturday" bushfires (Molyneaux et al., 2018, submitted). When people are forced to relocate, competition for resources (like jobs and land) between existing residents and new arrivals can increase racist sentiments and behaviour as currently seen in Europe and elsewhere with the upsurge in refugees from North Africa and the Middle East. For such reasons, climate change has been described as an "accelerant" and "threat multiplier" to political instability.

\subsubsection{Climate Change's Contribution to Structural Violence}

Perhaps more important than its impact on direct violence, climate change worsens the root causes of violence. In this context, it is instructive to consider the United Nation's Sustainable Development Goals (SDGs) which together constitute a plan of action to "strengthen universal peace in larger freedom" (United Nations, 2015). Climate change is the focus of the 13th SDG ("Take urgent action to combat climate change and its impacts"), where it is described as the single biggest threat to development (United Nations, 2015). However, it is also relevant to most of the other SDGs - impacts on some of these are summarised in Table 21.1 (see Sanson et al., 2018 , for further details). The deep asymmetry between those who have contributed 
Table 21.1 Examples of how climate change will impede the achievement of selected SDGs

\begin{tabular}{l|l}
\hline $\begin{array}{l}\text { Sustainable } \\
\text { Development } \\
\text { Goal (SDG) }\end{array}$ & Examples of how climate change will compromise achievement of SDG \\
\hline $\begin{array}{l}\text { SDG 1: End } \\
\text { poverty } \\
\text { and }\end{array}$ & $\begin{array}{l}\text { Climate change is disproportionately caused by "developed" (or "WEIRD"a) } \\
\text { countries which make up 12\% of the world's population. But, due to } \\
\text { geographic position (lower latitudes and lower altitudes) and weaker } \\
\text { infrastructure (such as transport, health, education and social welfare } \\
\text { Reduced } \\
\text { inequalities } \\
\text { term climate change effects and have less capacity to prepare for and recover } \\
\text { from them. Hence inequalities will increase, and tackling poverty will be } \\
\text { more challenging }\end{array}$ \\
\hline $\begin{array}{l}\text { SDG 2: Zero } \\
\text { hunger }\end{array}$ & $\begin{array}{l}\text { For every degree Celsius of warming, agricultural yields in Africa will } \\
\text { diminish by 10-30\%, directly threatening livelihoods (Hanna \& Oliva, 2016) }\end{array}$ \\
\hline $\begin{array}{l}\text { SDG 3: Good } \\
\text { health and } \\
\text { well-being }\end{array}$ & $\begin{array}{l}\text { The overall health impacts of climate change are predicted to be extremely } \\
\text { negative (Watts et al., 2018) (see Sect. 21.3) }\end{array}$ \\
\hline $\begin{array}{l}\text { SDG 4: Quality } \\
\text { education }\end{array}$ & $\begin{array}{l}\text { More frequent and intense floods, wildfires, hurricanes and other EWEs will } \\
\text { harm schooling by reducing attendance and achievement and destroying } \\
\text { schools and, particularly in LMICs, by children leaving school to work and } \\
\text { enhance family income (Kousky, 2016) }\end{array}$ \\
\hline $\begin{array}{l}\text { SDG 5: Gender } \\
\text { equality }\end{array}$ & $\begin{array}{l}\text { Girls tend to be removed from school in times of hardship more often than } \\
\text { boys (UNICEF, 2015) }\end{array}$ \\
\hline $\begin{array}{l}\text { SDG 16: Peace, } \\
\text { justice and } \\
\text { strong } \\
\text { institutions }\end{array}$ & $\begin{array}{l}\text { Climate change will cause political and societal instability and undermine } \\
\text { existing institutions (see Sect. 21.4.1) }\end{array}$ \\
\hline
\end{tabular}

aWEIRD stands for "Western, Educated, Industrialized, Rich and Democratic" countries which make up $12 \%$ of the world's population (Henrich, Heine, \& Norenzayan, 2010)

${ }^{b} \mathrm{LMICs}$, lower- and middle-income countries

least to our warming atmosphere but will be most heavily impacted and those who contributed most but will be better protected creates a situation of fundamental injustice and a clear case of structural violence on a global scale.

\subsection{A Fair and Just Response to Climate Change: Global and Community Solutions}

Approaches to mitigating the severity of climate change and adapting to its impacts should also seek to reduce the deep inequalities and injustices inherent in it, thereby also protecting children's well-being. In fact, climate change may offer an opportunity for building "positive peace" (Christie et al., 2001). Here we explore some of the ways in which climate solutions can help build more peaceful and equitable societies, starting with global solutions and moving to regional and local initiatives. 


\subsubsection{Global Solutions}

Climate change as a global problem requires global cooperation to bring about solutions. The UN Framework Convention on Climate Change (UN General Assembly, United Nations, 1994) requires nations to protect the climate system "on the basis of equity and in accordance with ... common but differentiated responsibilities and respective capabilities" and has a peace-building approach at its heart. From an ethical viewpoint, it is only fair that those who contributed most to the problem, and who possess the greatest resources, should bear the greatest burden for addressing it. To date, however, fair, cooperative and systemic approaches for global burdensharing have not emerged. The voluntary carbon reduction commitments made after the Paris Agreement are relatively weak and are insufficient to avoid dangerous climate change (Falkner, 2016). Nor is action happening fast enough.

Some argue that we should consider not only the divide between developed and developing states but also divides between affluent and poor people, wherever they live (Huntjens \& Zhang, 2016). Harris, Chow, and Karlsson (2013), for example, argue that the high-carbon lifestyles of the most affluent people (the wealthiest $10 \%$ who own $87.8 \%$ of the world's wealth; Credit Suisse, 2017) and the global middle class must be regulated and taxed so that the costs of adaptation are redistributed between the world's wealthy and the poor.

Other global solutions to simultaneously address climate change and work towards climate justice rely on whole-scale changes to current economic systems. Examples include moving beyond gross domestic product (GDP) as a measure of a country's prosperity, to a broader measure of overall well-being that includes health, education and security (Stiglitz, Sen, \& Fitoussi, 2010), or a measure like the Bhutanese Gross National Happiness Index which includes indicators of human well-being and environmental health. Others call for even more radical reordering of our economic and political system. According to Klein (2014), the current capitalist free market system is based on the fiction that nature is limitless. This has resulted in exploitation almost beyond the point of recovery - of the atmosphere, land, water and many species. To lower global emissions as rapidly as necessary, argues Klein, we need a completely different system: one that respects natural cycles of renewal; is sensitive to natural limits; generates plentiful, dignified work; closes deep inequalities; strengthens and transforms the public sphere; and radically reins in corporate power. Building equality and justice is deeply embedded in these types of solutions.

The discourse surrounding climate change often ignores or de-emphasises underlying structural political and economic problems, instead focusing on individualised lifestyle issues (Ojala, 2015). This is based on a neoliberal way of seeing people foremost as consumers rather than citizens, positing that people can take responsibility for global climate change by making the right consumer choices. While such individual choices are important, they will not in themselves prevent the escalation of climate change. Rather, to address the structural obstacles and injustices associated with climate change, people need to act as citizens, pressuring governments to 
make appropriate policy changes. "People power" will be a necessary ingredient in pushing national governments towards stronger action. Joining lobby or action groups (e.g. the Citizens' Climate Lobby) can help to overcome a sense of powerlessness and maximise the impact of individuals' actions at this level.

\subsubsection{Regional, Community and Local Solutions}

Proponents of climate solutions that move away from free market ideologies highlight the importance of the dispersal and devolution of power and control to regional and local communities (although strong central governments are still essential to set laws and limits to carbon-polluting activities). A worldwide movement of relocalisation seeks to build societies based on the local production of food, energy and goods and the local development of governance, currency and culture (http:// www.postcarbon.org/relocalize/). Massive cuts in emissions can be achieved by localising economies so that needs are met close to home, avoiding energy-intensive transportation (Norberg-Hodge, 2003). This shift would be facilitated by government regulations to rein in corporate power, involving change at national and international levels too.

The flourishing global "transition town" movement is a good example of grassroots-led re-localised economies (Hopkins, 2009). In transition towns, local communities make plans for how to transition away from fossil fuels and build in resilience for tough times ahead. They use collective decision-making and participatory democracy to build ideas about how to strengthen their local economies with low-carbon initiatives. These efforts revitalise or create new local businesses, stimulate local jobs and help create thriving communities of people with meaningful employment in their local area. Community-owned renewable energy projects, community gardens, car-share schemes, tool libraries and repair cafes are examples of climate solutions at regional and local levels which are proliferating around the world and building fairer, safer communities (Hopkins, 2013).

Redressing climate injustice and restoring a safe climate also involve shoring up communal infrastructure to provide essential services like public transport, housing and electricity that reduce emissions and are affordable and accessible to everyone. A growing trend is for local governments to lead change. For example, in 2016, Darebin (a municipality in Melbourne, Australia) became one of the first councils in the world to declare a climate emergency and is planning and implementing changes in areas including transport, green spaces, planning, waste minimisation, energy generation and efficiency and fossil fuel divestment (https://www.yoursaydarebin. com.au/21346/documents/62558). Other municipalities are following suit; amongst the first in the USA were Hoboken County in New Jersey, Montgomery County in Maryland and the city of Los Angeles. By mid 2019, 822 jurisdictions in 16 countries had declared a climate emergency (https://climateemergencydeclaration.org/ climate-emergency-declarations-cover-15-million-citizens/). 
There are multiple opportunities for engagement at the community or local level for individuals and organisations. For example, to support localisation efforts, community development activities can be undertaken by practitioners and scholars from a range of disciplines as well as civic leaders, activists and involved citizens. These activities can strengthen civil society by empowering and strengthening the capacity of people as active citizens, enabling them to shape change in their communities (Craig, Gorman, \& Vercseg, 2004). One among many potential roles for peace psychologists is to help build community capacity in the peace-building skills of negotiation, cooperation, conflict resolution and active communication which are vital to the successful development and operation of community-owned projects. All such initiatives seek to mitigate climate change and hence help to protect today's children and future generations from its most devastating effects.

\subsection{Supporting Children in the Face of Climate Change}

As noted above, individuals' actions as citizens can help mitigate climate change while simultaneously addressing inequity and injustice and building positive peace. Further, there are many ways in which children can be supported to cope with climate change that build their own capacities to take action on environmental threats. Below we start with the necessary step of overcoming denial and avoidance of the climate change problem. Then we turn to engagement of children in efforts at mitigation, followed by consideration of the skills and capacities they need to adapt to current and future climate change impacts and to be prepared for the major changes associated with a transition to a climate-changed world and low-carbon economy. We should note at the outset that virtually all the research looking at these questions has come from the "WEIRD" (developed) world, and many of the strategies we discuss are only accessible to those in developed nations or with relative wealth who are also those with the most responsibility, and power, to act. As discussed in Sect. 21.6.3, there is a clear need for more research on how to build the resilience of children in LMIC countries.

\subsubsection{Overcoming Denial and Avoidance of Climate Change}

Despite most people acknowledging that climate change is a problem requiring urgent changes in human behaviour (Cook et al., 2016; Reser, Bradley, Glendon, Ellul, \& Callaghan, 2012), far fewer people are taking active steps to mitigate it. Psychological factors are central to both denial of climate change and failure to act. These include cognitive biases like minimising threats which appear distant in time and space, avoidance of painful feelings, resisting change and filtering out information which conflicts with our belief systems (Centre for Research on Environmental Decisions [CRED], 2014). Psychology also provides insights into how effective 
action can be stimulated, by helping people (whether children or adults) come to terms with the profound implications of climate change, develop a sense of selfefficacy and collective efficacy and engage in actions which help manage their anxieties while contributing to climate mitigation (Burke, Sanson, \& Keast, 2017).

Overcoming denial and avoidance involves becoming more knowledgeable about the basic facts of climate change and its implications for future peace and stability in the world. A further critical step is to break the collective silence surrounding climate change - in other words, other people's avoidance and denial. Despite its urgency, not enough people talk about climate change on a regular basis (Norgaard, 2011). For example, a 2016 survey found that only 19\% of Americans hear someone they know talking about global warming at least once a month (Leiserowitz, Maibach, Roser-Renouf, Rosenthal, \& Cutler, 2017). We need to find ways to bring climate change into conversations with our colleagues, institutions, professional bodies and stakeholders - including those who don't share our worldview or beliefs, seeking to find common values (like protecting children's health) which can lead to common solutions (like clean energy). The more climate change is viewed as a risk that requires action, the more it amplifies an individual's own risk perception and intention to act (van der Linden, Maibach, \& Leiserowitz, 2015). Breaking the silence also includes advocating for action on climate change to politicians, policy-makers, opinion leaders and decision-makers.

We know the majority of children and youth have at least some concern about climate change, but they may not share these concerns with parents or other adults. To support children and young people in sharing their concerns and confronting the reality of climate change, important elements include providing supportive environments and opportunities for them to express their fears and concerns and have them validated; sharing your own concerns; suggesting ways to manage negative feelings; giving access to accurate information and dispelling misconceptions; and collaboratively thinking of things they can do about it (alone, with you, with peers or as part of a group) and supporting them in carrying out these ideas (Ojala \& Lakew, 2017). Parents and educators, but also others such as youth and community workers, can take on these support roles.

\subsubsection{Children as Active Agents in Responding to Climate Change}

While it is easy to see children as victims of environmental threats like climate change, they can also be powerful protagonists for change. The Convention on the Rights of the Child states that children have the right to participate in and influence decision-making processes that may be relevant in their lives (UN General Assembly, 1989). Climate change decision-making now will determine the lives of children far into the future, so it is right that children are invited to contribute. Being given the opportunity to actively contribute to combating climate change can also provide 
important psychological protection, "helping them to feel more in control, more hopeful and more resilient" (Hart, Fisher, \& Kimiagar, 2014, p.93). It is thus important to treat young people as active agents, to respect and support their capacities to take action, to work together and to support each other. Helping children develop effective ways of coping with climate change builds their resilience and well-being, while acknowledging the critical role that they, as the next generation of adults, will play in shaping global responses to climate change.

One effective strategy for children to use to cope with climate change is problemfocused coping which entails actively addressing an aspect of climate change (Ojala, 2012). Table 21.2 provides examples of climate change programmes illustrating different levels of child engagement, participation, co-agency and collaboration, as well as youth social action groups.

Another coping strategy is meaning-focused coping, which is particularly relevant for problems like climate change which cannot be removed or solved immediately or alone but demand active involvement over the longer term (Ojala, 2016). Meaning-focused coping involves concepts like positive reappraisal, in which the stressor is acknowledged but positive benefits are identified ("a zero-carbon world could be more healthy and fun"), and hope - recognising that big problems (like apartheid and women's voting rights) have been solved in the past and that new ways to address climate change are being developed all the time (Ojala, 2012). It thus includes a realistic appraisal of the threat, along with a positive attitude that overcomes despair and motivates action. Ojala (2012) has found that meaningfocused coping in children is related to pro-environmental behaviour, environmental efficacy, optimism and a sense of purpose. Meaning-focused coping is similar to Stoknes' (2015) concept of "authentic hope" and Macy and Johnstone's (2012) concept of "active hope".

Helping children to develop adaptive coping styles to engage with climate change can be the work of parents, carers, educators, community development workers and others and can be informed by the work of psychologists. While not much research has yet been published, climate literacy programmes for young people (e.g. http:// withoneplanet.org.au; https://www.freespirit.com/pages/resource.cfm?file=1920; Kaye, 2009) and resources to assist parents (e.g. Australian Psychological Society, 2018) are being developed. Strazdins and Skeat (2011) argue that building hopeful images of a zero-carbon future encourages young people to channel their individual interests into a higher social purpose and provides a broader sense of meaning in life. Grønhøj and Thøgersen (2017) specifically examined how different parenting styles can influence young people's internalised motivation to "do something for the environment". They identified four important factors: (i) letting young people see their parents are engaging in pro-environmental behaviours; (ii) parents having their own self-determined motivation to do things for the environment; (iii) an autonomysupporting parenting style in which parents listen to children's views and perspectives and allow them to decide things for themselves; and (iv) setting expectations for pro-environmental action. 


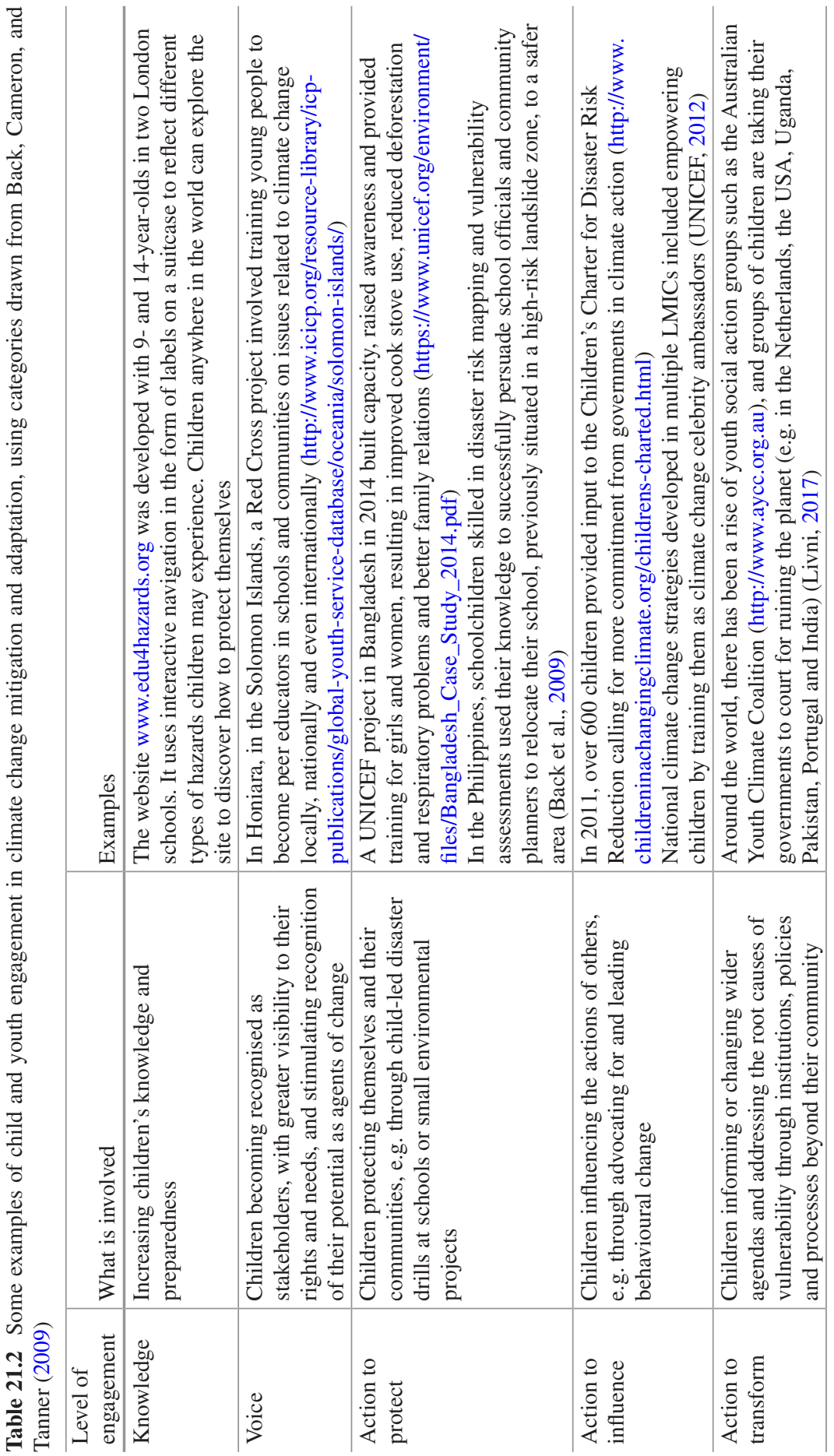




\subsubsection{Building Children's Resilience to Climate Change Impacts and a Zero-Carbon World}

As well as being engaged in pro-environmental behaviours and climate actions which build just and fair solutions, children and youth will also need support to be able to adapt to faster and more wide-ranging changes than we have ever seen before. On top of increasingly negative climate impacts, they will also need to adapt to massive changes in lifestyle, consumption, work and travel as the world shifts to a zero-carbon economy - requiring flexibility, adaptability and cooperation with others.

Models of positive child and adolescent development emerging from developmental psychology can provide guidance on how to build the capacities of youth to respond effectively as individuals, community members and citizens to the changes ahead. While a range of positive development models have been proposed (e.g. Hawkins, Letcher, Sanson, Smart, \& Toumbourou, 2009; Lerner, Almerigi, Theokas, $\&$ Lerner, 2005), they share a number of commonalities. They emphasise competence in (a) individual-level attitudes, values and behaviours such as self-esteem, self-efficacy, empathy and beliefs in justice and equity; (b) interpersonal spheres, reflected in healthy relationships with parents, peers and others and the capacity to cooperate and negotiate with others; and (c) at the community/social level, community involvement, civic action and engagement and trust and tolerance of others.

In general terms, these positive development attributes reflect eudaimonia (realising human potential through meaningful living) in contrast to hedonia (or pleasureseeking) and provide foundational capacities for resilience and adaptation in the face of the changes ahead. ${ }^{2}$ For example, to avoid violence breaking out in the face of climate-induced disruptions, skills in conflict resolution, problem-solving, intercultural understanding, empathy and acceptance and beliefs in environmental protection, equality and justice will be critical. To deal effectively with the move to a zero-carbon and more localised world, skills for cooperation and sharing, trust towards others and strong community orientation and civic engagement will be needed.

The question then is how can we build these attributes in the next generation? Hawkins et al. (2009) showed that four broad factors operating from childhood through early adolescence were related to positive development in early adulthood: self-regulation; positive and supportive relationships with parents, peers and teachers; school connectedness; and being a contributing member of their community, including volunteering and political awareness. Thus early efforts to strengthen

\footnotetext{
${ }^{2}$ In other climate-related literature, eudaimonic attributes are referred to as intrinsic values and contrasted with extrinsic values which are usually counterproductive in the drive to reduce greenhouse gas emissions. Intrinsic values provide a better source of motivation for engaging in biggerthan-self problems like climate change (https://valuesandframes.org/).
} 
children's capabilities in these areas may help them to thrive and be well-prepared for responding adaptively to the changes ahead. Efforts to support positive development could also focus on helping young people to develop a sense of individual empowerment and collective efficacy by being involved in small climate action projects; talking about values like equality and compassion in age-appropriate terms; encouraging volunteering and joining community groups; encouraging a deep connection with nature; modelling responsible political action; and promoting a climate in schools that values and promotes eudaimonic attributes as much as intellectual and occupational success.

The promotion of positive development, eudaimonic/intrinsic values and meaning-focused coping thus appear to be valuable approaches for preparing young people for the realities of climate change, as well as providing them with the active citizenship skills needed to promote speedy action to mitigate climate change and adapt to the inevitable changes. However, as noted above, the available research on these concepts has been almost entirely conducted in wealthy Western countries, and it is as yet uncertain how applicable they are for the non-Western LMICs which will bear the brunt of climate change. This is clearly an important area for future research.

\subsection{Summary and Conclusions}

Climate change is one of the most pervasive threats to peace, development, security, health and equity around the world in the twenty-first century, involving both episodic and structural violence. However, solving climate change is also one of our best hopes for episodic and structural peace-building, resulting in a healthier, fairer and more just world.

Children are particularly at risk, being developmentally most vulnerable to many climate impacts, some lasting over their entire lifetime. Focusing on children also helps us to see the injustice and urgency of addressing climate change and encouraging the current adult generation to recognise its responsibilities and "moral duty" (Cripps, 2017) to ensure that today's children and their descendants will have the basic conditions for flourishing. We have discussed peaceful and just solutions to the problem of climate change at all the ecological levels in Bronfenbrenner and Morris's (2006) model of development - some at the macro-system (global and regional) level, some at the exo-system (local and community) level and some at the meso- and micro-system (family, school, individual) levels. Each approach provides opportunities for educators, scholars, practitioners, policy-makers and activists to make valuable contributions. Community development principles can be applied in disaster risk reduction, re-localisation and community adaptation programmes, ensuring that children are heard and fully engaged. There are multiple possibilities for programme development, evaluation and implementation around promoting coping skills, positive development and civic engagement in young people so that 
they can cope and thrive in a climate-changed world. Globally, there is uneven coverage of climate change in schools: the UN Decade of Education for Sustainable Development (2005-2014; see https://en.wikipedia.org/wiki/Education_for_sustainable_development) helped develop the capacity of school systems to cover sustainable development in school curricula (e.g. Mwendwa, 2017). However, climate change is more rarely a specific curriculum topic. While excellent initiatives exist such as the US Alliance for Climate Education (https://acespace.org) which reports delivering climate education to over two million students, many students across the world still receive limited information. Further, in terms of offering students opportunities to engage with climate change mitigation, it is common for schools to focus only on consumer-based actions (e.g. reduce, reuse, repair, recycle). There is typically little emphasis on active citizenship, on respecting children's rights to full participation or on helping them to develop adaptive coping strategies for the future. Schools, clubs and community groups are among potential sites for programmes to develop these skills - there are many opportunities for educators and psychologists to collaborate in this area.

In tertiary education, there needs to be a much greater integration of climate change into all disciplines and subjects. US research indicates that the majority of undergraduate students do not have an accurate understanding of climate change nor its mitigation (Huxster, Uriber-Zarain, \& Kempton, 2015). Climate change, as a threat multiplier and complex global problem, affects every aspect of our lives and needs to be recognised as such. Whether thinking of the arts, architecture, planning, law or the health, social, biological or "hard" (e.g. engineering) sciences, it is difficult to think of an area of study that will not be affected by climate change but also has the potential to contribute to solutions. Within the psychology discipline specifically, climate change needs to be incorporated across all specialist areas, e.g. understanding its impacts on children's development, mental health and well-being; considering the demands on public health services that climate change impacts will entail; examining the human causes and solutions to climate change; and developing expertise in the peace-building skills of communication, conflict resolution and negotiation which will be so critical in the future.

Multidisciplinary collaboration to achieve effective solutions to climate change is essential. There is enormous scope for psychologists and other social scientists to work with the broader community of academics, policy-makers, scientists, community groups, activist organisations and the public in conducting climate change research and developing or implementing solutions to environmental threats and climate change. Global climate change is as much a social problem as a physical one.

In conclusion, the world is facing a dire predicament, and the challenges are massive and urgent. But we have the capacity to slow and then stop the harmful warming of our planet at the same time as building fair, just and peaceful communities. Whatever our roles in society, as today's adults, we need to accept that the future survival of our families, communities, the natural places we love and all future generations depends on the actions we take now. 


\section{References}

Agnew, R. (2011). Dire forecast: A theoretical model of the impact of climate change on crime. Theoretical Criminology, 16, 21-42. https://doi.org/10.1177/1362480611416843

Akresh, R. (2016). Climate change, conflict, and children. The Future of Children, 26, 51-72.

Albert, M., Hurrelmann, K., Quenzel, G., \& Jugend, G. (2010). Eine pragmatische Generation behauptet sich. (A pragmatic generation asserts itself). Frankurt am Main, Germany: Fischer Taschenbuch Verlag.

Anderson, C. A. (2012). Climate change and violence. In D. Christie (Ed.), The encyclopedia of peace psychology. Hoboken, NJ: Wiley-Blackwell.

Australian Psychological Society. (2018, under review). Raising children for a climate changed world: Parenting for sustainability information sheet. Australian Psychological Society.

Back, E., Cameron, C., \& Tanner, T. (2009). Children and disaster risk reduction: Taking stock and moving forward. UNICEF. Retrieved from: https://www.preventionweb.net/files/12085 ChildLedDRRTakingStock1.pdf

Betts, R. A., Jones, C. D., Knight, J. R., Keeling, R. F., \& Kennedy, J. J. (2016). El Niño and a record $\mathrm{CO} 2$ rise. Nature Climate Change, 6, 806.

Bronfenbrenner, U., \& Morris, P. A. (2006). The bioecological model of human development. In R. M. Lerner \& W. Damon (Eds.), Handbook of child psychology: Theoretical models of human development (Vol. 1, 6th ed., pp. 793-828). Hoboken: John Wiley \& Sons.

Burke, M., Hsiang, S. M., \& Miguel, E. (2015). Global non-linear effect of temperature on economic production. Nature, 527, 235.

Burke, S., Sanson, A., \& Keast, S. (2017). The climate change empowerment handbook. Melbourne. Melbourne, Australia: Australian Psychological Society. Retrieved from: https://www.psychology.org.au/APS/media/pdfs/Legacy/The-Climate-Change-Empowerment-Handbook.pdf

Centre for Research on Environmental Decisions [CRED]. (2014). Connecting on climate: A guide to effective climate change communication. Earth Institute, Columbia University. Retrieved from: http://ecoamerica.org/wp-content/uploads/2014/12/ecoAmerica-CRED-2014-Connecting-on-Climate.pdf

Christie, D. J., Wagner, R. V., \& Winter, D. D. (2001). Peace, conflict and violence. Peace psychology for the 21st century. Englewood Cliffs, NJ: Prentice-Hall.

Clayton, S., Manning, C., Krygsman, K., \& Speiser, M. (2017). Mental health and our changing climate: Impacts, implications, and guidance. Washington, D.C.: American Psychological Association and ecoAmerica. Retrieved from: http://ecoamerica.org/wp-content/ uploads/2017/03/ea-apa-psych-report-web.pdf

Confalonieri, U. B., Menne, R., Akhtar, K. L., Ebi, M., Hauengue, R. S., Kovats, B., ... Woodward, A. (2007). Human health. In M. L. Parry, O. F. Canziani, P. J. Palutikof, P. J. van der Linden, \& C. E. Hanson (Eds.), Climate change 2007: Impacts, adaptation and vulnerability. Contribution of Working Group II to the Fourth Assessment Report of the Intergovernmental Panel on Climate Change (pp. 391-431). Cambridge, UK: Cambridge University Press.

Cook, J., Oreskes, N., Doran, P. T., Anderegg, W. R. L., Verheggen, B., Maibach, E. W., ... Rice, K. (2016). Consensus on consensus: A synthesis of consensus estimates on human-caused global warming. Environmental Research Letters, 11, 048002. https://doi. org/10.1088/1748-9326/11/4/048002

Costello, A., Abbas, M., Allen, A., Ball, S., Bell, S., Bellamy, R., ... Patterson, C. (2009). Managing the health effects of climate change. The Lancet, 373, 1693-1733. https://doi.org/10.1016/ S0140-6736(09)60935-1

Craig, G., Gorman, M., \& Vercseg, I. (2004). The Budapest Declaration: Building European civil society through community development. International Association for Community Development. Retrieved from: http://www.communitydevelopmentalliancescotland.org/documents/inPractice/BudapestDeclaration.pdf

Credit Suisse. (2017). Global Wealth Report 2017. Credit Suisse Research Institute. Retrieved from: http://publications.credit-suisse.com/index.cfm/publikationen-shop/research-institute/ global-wealth-report-2017-en/ 
Cripps, E. (2017). Do parents have a special duty to mitigate climate change? Politics, Philosophy \& Economics, 16, 308-325. https://doi.org/10.1177/1470594X17709038

Ebi, K. L. (2014). Childhood health risks of climate change. In The challenges of climate change: Children on the front line (pp. 22-25). Innocenti Insight, Florence, Italy: UNICEF Office of Research.

Falkner, R. (2016). The Paris Agreement and the new logic of international climate politics. International Affairs, 92, 1107-1125. https://doi.org/10.1111/1468-2346.12708

Garcia, D. \& Sheehan, M. (2016). Extreme weather-driven disasters and children's health. International Journal of Health Services, 46, 79-105.

Grantham-McGregor, S., Cheung, Y., Cuato, S., Glewwe, P., Richter, L., Strupp, B., \& International Child Development Steering Group. (2007). Developmental potential in the first 5 years for children in developing countries. Lancet, 369, 60-70.

Grønhøj, A., \& Thøgersen, J. (2017). Why young people do things for the environment: The role of parenting for adolescents' motivation to engage in pro-environmental behaviour. Journal of Environmental Psychology, 54, 11-19. https://doi.org/10.1016/j.jenvp.2017.09.005

Hanna, R., \& Oliva, P. (2016). Children and climate change. The Future of Children, 26, 115-132.

Harris, P. G., Chow, A. S. Y., \& Karlsson, R. (2013). China and climate justice: Moving beyond statism. International Environmental Agreements: Politics, Law and Economics, 13, 291-305. https://doi.org/10.1007/s10784-012-9189-7

Hart, R., Fisher, S., \& Kimiagar, B. (2014). Beyond projects: Involving children in community governance as a fundamental strategy for facing climate change. In The challenges of climate change: Children on the frontline (pp. 92-97). Florence, Italy: UNICEF Office of Research.

Hawken, P. (2017). Drawdown: The most comprehensive plan ever proposed to reverse global warming. New York, NY: Penguin Books.

Hawkins, M. T., Letcher, P., Sanson, A., Smart, D., \& Toumbourou, J. W. (2009). Positive development in emerging adulthood. Australian Journal of Psychology, 61, 89-99. https://doi. org/10.1080/00049530802001346

Henrich, J., Heine, S. J., \& Norenzayan, A. (2010). Most people are not WEIRD. Nature, 466, 29. https://doi.org/10.1038/466029a

Hopkins, R. (2009). The transition handbook: From oil dependency to local resilience. White River Junction, VT: Chelsea Green Pub.

Hopkins, R. (2013). The power of just doing stuff: How local action can change the world. Cambridge, UK: Green Books.

Huntjens, P., \& Zhang, T. (2016). Climate justice: Equitable and inclusive governance of climate action (Working paper No. 16). The Hague Institute for Global Justice. Retrieved from: http:// www.thehagueinstituteforglobaljustice.org/information-for-policy-makers/working-paper/ climate-justice-equitable-and-inclusive-governance-of-climate-action/

Huxster, J. K., Uriber-Zarain, X., \& Kempton, W. (2015). Undergraduate understanding of climate change: The influences of college major and environmental group membership on survey knowledge scores. The Journal of Environmental Education, 46, 149-165.

IPCC. (2014). Climate change 2014: Synthesis report. Contribution of working groups I, II and III to the Fifth Assessment Report of the Intergovernmental Panel on Climate Change (p. 151). Geneva, Switzerland. Retrieved from: http://www.ipcc.ch/report/ar5/syr/

Kaye, C. B. (2009). A kids' guide to climate change and global warming: How to take action. Minneapolis, MN: Free Spirit Pub.

Klein, N. (2014). This changes everything. London, UK: Penguin Books Ltd.

Kousky, C. (2016). Impacts of natural disasters on children. The Future of Children, 26, 73-92.

Leiserowitz, A., Maibach, E., Roser-Renouf, C., Rosenthal, S., \& Cutler, M. (2017). Climate change in the American mind: November 2016. Yale University and George Mason University. New Haven, CT: Yale Program on Climate Change Communication.

Lerner, R., Almerigi, J. B., Theokas, C., \& Lerner, J. V. (2005). Positive youth development: A view of the issues. Journal of Early Adolescence, 25, 10-16.

Livni, E. (2017). Quartz. Retrieved from: https://qz.com/1156876/juliana-vs-usakids-are-suing-over-climate-change/ 
Macy, J., \& Johnstone, C. (2012). Active hope: How to face the mess we're in without going crazy. Novato, CA: New World Library.

McMichael, A. J. (2014). Climate change and children: Health risks of abatement inaction, health gains from action. Children, 1, 99-106. https://doi.org/10.3390/children1020099

McMichael, A. J., Campbell-Lendrum, D., Kovats, S., Edwards, S., Wilkinson, P., Wilson, T., ... Andronova, N. (2004). Global climate change. In M. Ezzati, A. Lopez, A. Rodgers, \& C. Murray (Eds.), Comparative quantification of health risks: Global and regional burden of disease due to selected major risk factors (pp. 1543-1649). Geneva, Switzerland: World Health Organization.

Molyneaux, R., Gibbs, L., Bryant, R. A., Humphreys, C, Hegarty, K., ... \& Forbes D. (2018). Interpersonal violence and mental health outcomes following disaster. Manuscript submitted for publication.

Mwendwa, B. (2017). Learning for sustainable development: Integrating environmental education in the curriculum of ordinary secondary schools in Tanzania. Journal of Sustainability Education, 12. Retrieved from: http://www.susted.com/wordpress/wp-content/ uploads/2017/02/Mwendwa-JSE-Feb-2017-General-Issue-PDF.pdf

NOAA. (2017). Global Climate Report - Annual 2016. National Centers for Environmental Information. Retrieved from: https://www.ncdc.noaa.gov/sotc/global/201613

Norberg-Hodge, H. (2003). Globalisation: Use it or lose it. The Ecologist, 33, 23-25.

Norgaard, K. M. (2011). Living in denial: Climate change, emotions, and everyday life. Cambridge, MA: The MIT Press. https://doi.org/10.7551/mitpress/9780262015448.001.0001

Ojala, M. (2012). How do children cope with global climate change? Coping strategies, engagement, and well-being. Journal of Environmental Psychology, 32, 225-233. https://doi. org/10.1016/j.jenvp.2012.02.004

Ojala, M. (2015). Hope in the face of climate change: Associations with environmental engagement and student perceptions of teachers' emotion communication style and future orientation. The Journal of Environmental Education, 46, 133-148. https://doi.org/10.1080/00958964.201 5.1021662

Ojala, M. (2016). Young people and global climate change: Emotions, coping, and engagement in everyday life. In N. Ansell, N. Klocker, \& T. Skelton (Eds.), Geographies of global issues: Change and threat (pp. 329-346). Singapore: Springer Singapore. https://doi. org/10.1007/978-981-4585-54-5_3

Ojala, M., \& Lakew, Y. (2017). Young people and climate change communication. Oxford Research Encyclopedia of Climate Science. https://doi.org/10.1093/acrefore/9780190228620.013.408

Reser, J. P., Bradley, G., Glendon, G. L., Ellul, M., \& Callaghan, R. (2012). Public risk perceptions, understandings and responses to climate change and natural disasters in Australia and Great Britain (No. 17/12). National Climate Change Adaptation Research Facility (NCCARF).

Sanson, A. V. (2017). Developmental science's role in responding to the climate crisis. ISSBD Bulletin, 1, 10-15.

Sanson, A. V., Wachs, T. D., Koller, S. H., \& Salmela-Aro, K. (2018). Young people and climate change: The role of developmental science. In S. Verma \& A. Peterson (Eds.), Sustainable Development Goals for children: Using developmental science to improve young lives globally. (pp115-138). New York, NY: Springer.

Sheffield, P. E., \& Landrigan, P. J. (2010). Global climate change and children's health: Threats and strategies for prevention. Environmental Health Perspectives, 119, 291-298. https://doi. org/10.1289/ehp. 1002233

Stiglitz, J. E., Sen, A., \& Fitoussi, J.-P. (2010). Mismeasuring our lives: Why GDP doesn't add up. New York, NY: New Press.

Stoknes, P. E. (2015). What we think about when we try not to think about global warming: Toward a new psychology of climate action. White River Junction, VT: Chelsea Green Publishing.

Strazdins, L., \& Skeat, H. (2011). Weathering the future: Climate change, children and young people, and decision making. Canberra, Australia: Australian Research Alliance for Children and Youth. Retrieved from http://www.aracy.org.au/publicationDocuments/ARACY\%20climate\%20change\%20report\%20March\%202011\%20FINAL\%20full1.pdf 
Strife, S. J. (2012). Children's environmental concerns: Expressing ecophobia. The Journal of Environmental Education, 43, 37-54. https://doi.org/10.1080/00958964.2011.602131

The Child Protection Working Group. (2015). A matter of life and death: Child protection programming's essential role in ensuring child wellbeing and survival during and after emergencies. The Child Protection Working Group. Retrieved from: http://cpwg.net/?get=010222/2015/10/A_ Matter_of_life_and_death_LowRes.pdf

The Royal Society. (2017). Climate updates. What have we learnt since the IPCC 5th Assessment Report? London, UK: The Royal Society. Retrieved from: royalsociety.org/climate-change

Tranter, B., \& Skrbis, Z. (2014). Political and social divisions over climate change among young Queenslanders. Environment and Planning A, 46, 1638-1651. https://doi.org/10.1068/a46285

UN General Assembly. (1989). Convention on the Rights of the Child (Treaty Series No. 1577) (p. 3). United Nations. Retrieved from: http://www.refworld.org/docid/3ae6b38f0.html

UN General Assembly, United Nations. (1994). Framework convention on climate change: Resolution adopted by the General Assembly. Retrieved from: http://www.refworld.org/ docid/3b00f2770.html

UNICEF. (2012). Climate change adaptation and disaster risk reduction in the education sector: Resource manual. UNICEF. Retrieved from: https://www.unicef.org/publications/ index_68843.html

UNICEF. (2014). The challenges of climate change: children on the front line. Florence, Italy: UNICEF Office of Research - Innocenti.

UNICEF. (2015). Unless we act now. New York, NY: United Nations Children's Fund. Retrieved from https://www.unicef.org/publications/files/Unless_we_act_now_The_impact_of_climate_ change_on_children.pdf

UNICEF UK. (2013). Climate change: Children's challenge. UNICEF UK. Retrieved from https:// downloads.unicef.org.uk/wp-content/uploads/2013/09/unicef-climate-change-report-2013. pdf?_ga=2.115858243.495899391.1517286128-426487953.1517286128

United Nations. (2015). Transforming our world: The 2030 agenda for sustainable development. United Nations. Retrieved from: https://sustainabledevelopment.un.org/content/documents/21252030\%20Agenda\%20for\%20Sustainable\%20Development\%20web.pdf

van der Linden, S., Maibach, E., \& Leiserowitz, A. (2015). Improving public engagement with climate change: Five "best practice" insights from psychological science. Perspectives on Psychological Science, 10, 758-763. https://doi.org/10.1177/1745691615598516

Watts, N., Amann, M., Ayeb-Karlsson, S., Belesova, K., Bouley, T., Boykoff, M., ... Costello, A. (2018). The Lancet Countdown on health and climate change: From 25 years of inaction to a global transformation for public health. The Lancet, 391(10120), 581-630. https://doi. org/10.1016/S0140-6736(17)32464-9

Yun, K., Lurie, N., \& Hyde, P. S. (2010). Moving mental health into the disaster-preparedness spotlight. New England Journal of Medicine, 363, 1193-1195. https://doi.org/10.1056/ NEJMp1008304

Open Access This chapter is licensed under the terms of the Creative Commons Attribution 4.0 International License (http://creativecommons.org/licenses/by/4.0/), which permits use, sharing, adaptation, distribution and reproduction in any medium or format, as long as you give appropriate credit to the original author(s) and the source, provide a link to the Creative Commons license and indicate if changes were made.

The images or other third party material in this chapter are included in the chapter's Creative Commons license, unless indicated otherwise in a credit line to the material. If material is not included in the chapter's Creative Commons license and your intended use is not permitted by statutory regulation or exceeds the permitted use, you will need to obtain permission directly from the copyright holder.

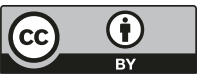

